\title{
The Humanization of Early Children Education
}

\author{
Made Saihu', Nasaruddin Umar² \\ DOI: 10.35445/alishlah.v13i1.419
}

\begin{abstract}
Info Artikel
Abstract

Keywords: Early Childhood Humanistic Theory Joy full Learning Integrated Learning Thematic Learning

This study discusses the teaching-learning process seen from the humanistic education theory from Carl Ransom Rogers at Asmaul Husna Learning Park, South Jakarta. This paper focuses on the educational perspective's operation through fun learning techniques, integrated learning, and thematic learning. In this paper, the data sources are obtained through field observations and structured interviews from January to July 2019 using the case study method. Through the humanistic educational theory approach, this educational study is the importance of understanding the character and potential of early childhood to optimally develop children intellectual, emotional, and spiritual intelligence. Although sometimes some students are disobedient or lazy to take part in learning, teachers and institutional managers anticipate this by presenting information about child development. Even to a certain extent, the institution also includes parents to participate in learning activities together. Here is also the importance of a teacher's creativity in communicating, choosing parenting styles, and various other stimulations when carrying out the teaching and learning process in class and outside the classroom. Without teachers' creativity in teaching and learning, the improvement and enhancement of cognitive, affective, and psychomotor aspects will not be optimal. An educational perspective places the humanization aspect as the basis for transferring knowledge, transferring human values, and transferring happiness.
\end{abstract}

Kata kunci:

Anak Usia Dini

Teori Humanistik

Joy full learning

Integrated Learning

Thematic Learning

\section{Abstrak}

Kajian ini membahas tentang proses belajar mengajar dilihat dari sudut pandang teori pendidikan humanistik dari Carl Ransom Rogers di Taman Belajar Asmaul Husna Petukangan Utara Jakarta Selatan. Kajian ini fokus pada operasionalisasi perspektif pendidikan melalui teknik belajar joyfull learning, integrated learning, dan thematic learning. Sumber data dalam tulisan ini diperoleh melalui observasi lapangan dan wawancara tak terstruktur selama bulan Januari sampai dengan bulan Juli 2019 dengan menggunakan metode studi kasus. Melalui pendekatan teori pendidikan humanistik yang menegaskan bahwa pentingnya pemahaman terhadap perbedaan karakter dan potensi yang dimiliki oleh anak usia dini, sehingga guru dapat secara maksimal mengembangkan kecerdasan intelektual, emosional, dan spiritual anak. Meski terkadang ada beberapa peserta didik yang tidak patuh atau malas dalam mengikuti pembelajaran, guru, dan pengelola lembaga mengantisipasinya melalui pemberian informasi tentang perkembangan anak. Bahkan dalam kadar tertentu, pihak lembaga juga mengikut sertakan para orang tua untuk sama-sama ikut serta dalam aktivitas pembelajaran. Di sini juga memperlihatkan pentingnya kreativitas seorang guru dalam berkomunikasi, memilih pola asuh, dan berbagai stimulasi lainnya ketika melaksanakan proses belajar-mengajar di kelas maupun di luar kelas. Tanpa adanya kreativitas guru

\footnotetext{
${ }^{1}$ Institut PTIQ Jakarta, Indonesia

Email: : madesaihu@ptiq.ac.id

${ }_{2}^{2}$ Universitas Islam Negeri Syarif Hidayatullah, Jakarta, Indonesia

Email: nasaruddin.umar@uin.jkt.ac.id

Vol.13 (1) June, 2021

Received: February 26, 2021; Received in revised form: March 9, 2021; Accepted: March 16, 2021; Available online: April 10, 2021

This is an open access article under a Creative Commons Attribution-NonCommercial-ShareAlike 4.0 International License
} 
dalam aktivitas belajar-mengajar, pengembangan dan peningkatan aspek kognitif, afektif, dan psikomotor menjadi tidak maksimal. Sebuah perspektif pendidikan yang mendudukkan aspek humanisasi sebagai dasar dalam mentransfer pengetahuan, mentransfer nilai-nilai kemanusiaan, dan mentransfer kebahagiaan.

\section{PENDAHULUAN}

Peletakan landasan bagi perkembangan pikiran, kepribadian, serta karakter anak sangat ditentukan oleh proses pembelajaran yang diberikan dan ditanamkan oleh orang tua sejak anak berusia o sampai 6 tahun (Nilma Zola, 2017, hal. 109-114). Pendidikan Anak Usia Dini (PAUD) memiliki tempat yang sangat strategis dalam mempersiapkan sumber daya manusia masa depan. Fakta menunjukkan bahwa perkembangan intelektual terjadi sangat cepat pada tahun-tahun awal kehidupan seorang anak, berbagai penelitian juga memperlihatkan bahwa pembentukan karakter manusia juga terjadi pada usia dini (Mulyasa, 2012, hal. 16). Karakteristik anak usia dini secara menyeluruh adalah unik, memiliki kekhasan dalam bertingkah laku, mungil, lucu, menyenangkan, menggemaskan, bahkan terkadang membuat orang dewasa merasa kesal (Masdudi, 2016, hal. 1-26).

Masa usia dini merupakan masa keemasan dimana perkembangan fisik, motorik, intelektual, emosional, linguistik dan sosial sangat pesat, bahkan perkembangan intelektual anak terjadi sebelum anak berusia 4 tahun, sehingga peningkatan kualitas anak usia dini dilakukan semaksimal mungkin, mengingat optimalisasi kualitas manusia harus memiliki landasan yang kuat sejak awal kehidupan (Nasution, 2017, hal. 1-16).

Periode usia dini merupakan masa yang sangat penting dan harus ditangani secara khusus sedini mungkin (Hurlock, 2013, hal. 36). Periode ini (3-6 tahun) merupakan masa sensitif pada anak, yaitu masa yang suatu fungsi tertentu pada jiwa anak harus dirangsang agar perkembangannya tidak terhambat (Mariana, 2019, hal. 58-66). Selama periode ini, anak-anak juga harus didorong untuk mengembangkan inisiatif dan kreatifitas seperti mengajukan pertanyaan berdasarkan apa yang mereka lihat, dengar, dan rasakan. Apapun yang dilakukan seorang anak dalam konteks pendidikan humanistik yang positif dapat dibenarkan selama tidak membatasi hak-hak anak sebagai individu yang bebas (Bahri, 2018, hal. 173-210). Pilihan yang ditawarkan dalam pendidikan humanistik adalah dengan memanfaatkan yang terbaik sebagai bagian dari pola pendidikan yang selaras dengan karakter bangsa Indonesia yang berbudi luhur dan religius (Usman, 2017, hal. 95-113). Apalagi konsep pendidikan humanisme adalah sebuah pendidikan yang berupaya menggali, melayani, menghargai, serta memotivasi dan membantu anak agar berbagai potensi terpendam yang dimilikinya dapat berkembang dengan baik sehinga anak dapat menjadi generasi religius, cerdas, peka terhadap perkembangan zaman, dan berakhlak mulia, yang ini semuai harus dimulai dari pendidikan dasar (Wigati I, 2017, hal. 1-17) .

Kajian ini memfokuskan pada operasionalisasi teori pendidikan humanistik di Taman Belajar Asmaul Husna Jakarta Selatan yang menggali potensi anak serta dapat meningkatkan kecerdasan intelektual, kecerdasan emosional, kecerdasan spiritual anak. Taman Asmaul Husna memiliki sejarah pendirian dan dinamika perjalanannya yang begitu kompleks, yaitu rasa adanya rasa kemanusiaan dan keprihatinan yang tinggi. Hal ini dapat dilihat dari keprihatinan pengelola bahwa banyak anak-anak usia 4-6 tahun yang berkumpul, berkerumunan, bermain-main di jalan dan di gang-gang tanpa adanya kegiatan edukatif. Dari sini Siti Wahyuni (pendiri), berinisiatif mendirikan lembaga pendidikan. Dipilihnya nomenklatur taman belajar bukan TK (Taman kanak-kanak) dikarenakan adanya anggapan masyarakat sekitar bahwa TK, meski aktivitas di dalamnya banyak permainan, tetapi bagi anak dan orang tua di daerah ini merasa terbelenggu oleh aturan yang formalistik. Dipilihnya nama taman belajar sebagai solusi atas keengganan masyarakat sekitar untuk memasukkan anak mereka ke TK. Selain itu istilah taman identik dengan segala sesuatu yang menyenangkan jadi sangat diharapkan dari awal dan menghibur dengan menjadikan metode playing game (metode bermain) sebagai acuan dalam proses belajar mengajarnya. 
Di tengah menjamurnya kajian tentang pendidikan anak usia dini dalam berbagai perspektif perkembangan media pembelajaran, seperti game education (Lucas, 2017, hal. 908-913), supervisi akademik (Kusumawati, 2016, hal. 1-8), standar proses pembelajaran (Nurdin, 2020, hal. 983-992), manajemen pengelolaan PAUD (Nurjanah, 2018, hal. 247-258), perbaikan mental (Lestari, 2019, hal. 8-17), hakikat pendidikan anak usia dini (Huliyah, 2016, hal. 71-89), implementasi kurikulum 2013 pada PAUD (Rahelly, 2018, hal. 381-390), profesionalisme guru PAUD (Fahruddin, 2018, hal. 37-44), hingga pengasuhan anak dan keterlibatan orang tua (Qurrota A'yun, 2016, hal. 33-40). Beberapa tulisan tentang kompleksitas pembelajaran di PAUD sudah banyak dikaji, tetapi tidak banyak yang menjelaskan tentang bagaimana mengembangkan potensi anak usia dini melalui perspektif teori pendidikan humanistik sebagai salah satu faktor penopang pengembangan potensi dan kecerdasan anak. Kajian ini menjelaskan pentingnya perspektif teori pendidikan humanistik sebagai salah satu teori dasar dalam pembelajaran di PAUD. Sebuah cara pandang lain dalam melihat proses belajar mengajar di sebuah lembaga pendidikan yang didominasi oleh ekspresi cipta, karya dan karsa dan harus dikembangkan pada anak usia dini, yaitu dengan melatih kepekaan melalui praktik interaksi terapeutik (person centered therapy).

\section{METODE}

Jenis penelitian kualitatif dipilih dalam tulisan ini yang bertujuan untuk memahami situasi dan kondisi sosial yang terjadi, menjabarkan dan menganalisis segala aktivitas pembelajaran di Taman Belajar Asmaul Husna, yaitu berupa uraian-uraian atau deskripsi, gambar-gambar, dan bukan angkaangka, karena memang penelitian kualitatif merupakan suatu kebiasan tertentu dalam ilmu pengetahuan sosial yang secara fundamental bergantung pada pengamatan manusia dalam kemasannya sendiri dan berhubungan dengan orang tersebut dalam bahasannya dan dalam perhatiannya (Moleong, 2016, hal. 3). Dipilihnya Taman Belajar Asmaul Husna, dikarenakan lokus penelitian tersebut memiliki peserta didik dengan latar belakang berbeda sehingga berdampak pada perbedaan karakteristik disebabkan oleh latar belakangnya.

Proses kerja dari penelitian ini dimulai dari bulan Januari sampai dengan Juni 2020 dengan menggunakan metode studi kasus melalui prosedur wawancara dan dokumentasi. Wawancara dilakukan kepala sekolah orang yang paling bertanggung jawab atas segala proses belajar mengajar di Taman Belajar Asmaul Husna Teknik selanjutnya adalah dokumentasi dan pengecekan keabsahan data yang dapat dijelaskan dalam gambar dibawah:

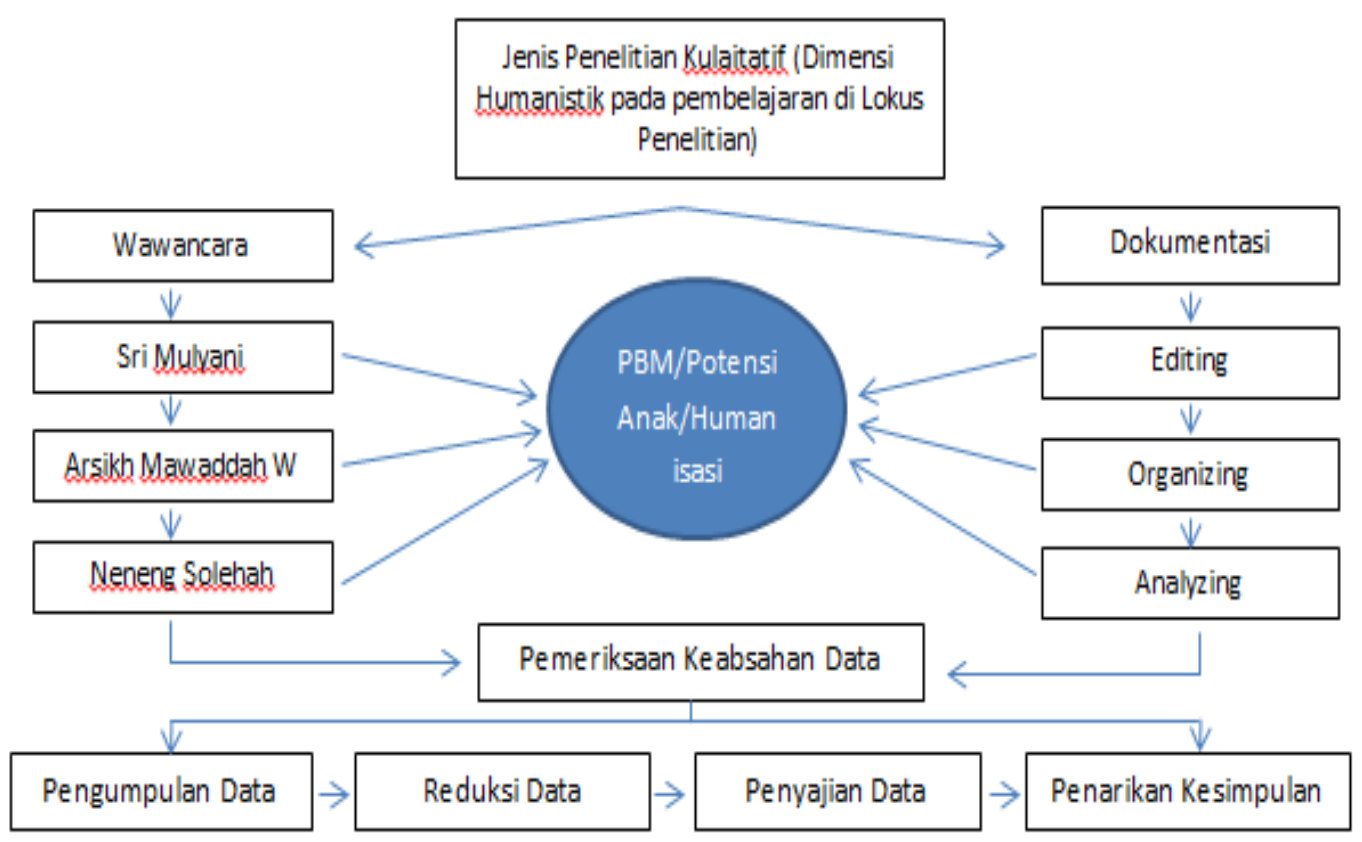

Gambar: 1. Skema Metode Penelitian 
Skema metode penelitian seperti ini, dapat memudahkan dalam menelaah potensi anak usia dini di Taman Belajar Asmaul Husna melalui pendekatan teori belajar humanistik dalam perspektif Carl Ransom Rogers.

\section{HASIL PENELITIAN DAN PEMBAHASAN}

\section{Teori Belajar Humanistik Carl Ransom Rogers}

Dalam kajian pendidikan, perspektif teori humanistik digunakan dalam menjelaskan tentang perkembangan pribadi melalui latihan sensitivitas (Natalie Shefer, 2018, hal. 63-81). Roger, psikolog asal Chicago Amerika ini menjelaskan dalam doktrin, sikap, dan gaya hidup yang berpusat pada nilainilai kemanusiaan dan menekankan pada kehormatan, martabat, dan kemampuan mewujudkan diri untuk tujuan tertentu (Anwar, 2017, hal. 225). Sebagai salah satu pendiri Gerakan Potensi Manusia, gerakan ini menekankan pada pengembangan pribadi melalui latihan kepekaan, pertemuan kelompok dan latihan lainnya yang dirancang untuk membantu orang memiliki kepribadian yang sehat. Rogers menetapkan teorinya sendiri berdasarkan praktik interaksi terapeutik dengan pasien. Karenanya teori yang dibangunnya dinamakan person-centered therapy (Syamsu Yusuf, 2007, hal. 143). Teori pusat terapi tidak mengevaluasi atau memberikan panduan, tetapi hanya untuk membantu siswa mengklarifikasi identitas mereka. Menurut ilmu psikologi, upaya menemukan jati diri merupakan salah satu cara untuk memperbaiki suatu kondisi, di sinilah letak sikap humanistik (Anwar, 2017, hal. 228).

Asumsi dasar dari teori Rogers adalah: 1) Kecenderungan pembentukan, yaitu semua benda organik dan non-organik di dunia tersusun dari benda-benda yang lebih kecil; 2) Kecenderungan realisasi, yaitu kecenderungan dari masing-masing organisme untuk menyempurnakan atau merealisasikan potensinya karena setiap orang memiliki usaha dan kreativitas untuk memecahkan masalah sendiri (Herpratiwi, 2016, hal. 30). Melihat diri sendiri adalah serangkaian konsepsi dan kepercayaan diri yang konsisten dan teratur (J. Feist, 1998, hal. 461). Perangkat sentral yang paling menentukan persepsi perilaku adalah persepsi diri atau konsep diri. Diri mencakup semua pikiran, konsep, dan nilai yang menjadi ciri pribadi, termasuk preferensi atau persepsi tentang diri sendiri (kesadaran akan keberadaan) dan apa yang lakukan dan dikerjakan (kesadaran akan fungsi). Pada gilirannya, ego memengaruhi persepsi orang tentang dunia dan perilakunya. Seseorang dengan konsep diri yang kuat dan positif pasti memiliki cara pandang yang berbeda terhadap dunia dibandingkan dengan konsep diri yang lemah yang berdampak pada perilakunya. Inti dari kepribadian dirangkum dalam aspek-aspek berikut: kepribadian, sosialitas dan moralitas hanya dapat menjadi kenyataan (tingkah laku, sikap) melalui pendidikan yang diarahkan pada diri sendiri (harga diri, kemandirian, kepercayaan diri) dapat menumbuhkan rasa percaya diri dan memiliki kepribadian yang kuat (Saihu, 2019, hal. 209).

Selain itu, Rogers, berpendapat bahwa aktivitas belajar adalah sebuah proses bimbingan kepada anak-anak agar anak mendapatkan kebebasan dan kemandirian, memahami proses yang baik dan yang jahat, serta dikenalkan pada proses membuat pilihan perilaku dan memiliki rasa tanggung jawab (Dincer, 2019, hal. 2341-2358). Hanya dengan memberikan kebebasan kepada anak sejak awal, mereka dapat mencapai kebebasan dalam jangkauan belajar mereka dan dengan demikian belajar yang bebas dapat menumbuhkan kemandirian. Rogers, memiliki prinsip-prinsip belajar sebagai berikut: Pertama, hasrat belajar. Pandangan ini berpendapat bahwa manusia memiliki keinginan bawaan untuk belajar. Ketika ada kesempatan untuk menjelajah lingkungan, rasa ingin tahu yang tinggi dari sang anak membuktikan hal tersebut. Keingintahuan yang mendorong pembelajaran adalah asumsi dasar pendidikan humanistik. Dalam kelas humanistik, anak-anak memiliki kesempatan dan kebebasan untuk memuaskan rasa ingin tahunya, menyadari minat mereka, dan menemukan beberapa hal penting dan bermakna tentang dunia di sekitar mereka.

Kedua, belajar yang berarti. Menurut Rogers, bahwa jika apa yang dipelajari oleh peserta didik berkaitan langsung dengan kebutuhan dan niatnya, maka pembelajaran itu akan memiliki makna. Dengan kata lain, jika apa yang peserta didik pelajari bermakna, maka perserta didik akan belajar dengan cepat. Oleh karena itu dalam pembelajaran pendidik hendaknya mengolah dan menyiapkan 
materi pembelajaran yang menyentuh langsung kepada jiwa peserta didik; Ketiga, belajar tanpa ancaman. Di sini, Rogers, menitikberatkan pada rasa kenyamanan dan sisi keamanan dalam proses pembelajaran. Menurutnya, Jika proses pembelajaran dilakukan di lingkungan yang bebas dari ancaman maka proses pembelajaran akan mudah dilanjutkan dan hasilnya dapat disimpan dengan baik. Ketika peserta didik dapat menguji kemampuannya, mencoba pengalaman baru dan membuat kesalahan tanpa dikritik yang biasanya menyinggung mereka, proses pembelajaran akan berjalan dengan lancar; Keempat, belajar atas inisiatif sendiri. Hal tersebut menunjukkan bahwa peserta didik memiliki motivasi internal yang tinggi. Peserta didik dengan banyak inisiatif akan dapat membimbing diri mereka sendiri, membuat pilihan sendiri, dan mencoba mempertimbangkan apa yang baik untuk mereka; Kelima, belajar dan perubahan. Ketika situasi dan kondisi dunia terus berubah, peserta didik harus belajar beradaptasi dan beradoptasi dengan perubahan kondisi dan situasi tersebut. Dengan demikian, belajar yang hanya mengingat fenomena atau peristiwa ingatan dianggap tidak cukup (Anwar, 2017, hal. 239).

Aplikasi teori Rogers, menempatkan pendidik sebagai fasilitator. Agar fungsi pendidik sebagai fasilitator dapat berperan secara optimal, maka dibutuhkan 3 sikap: Pertama, pendidik harus memiliki realitas saat menjadi fasilitator belajar; Kedua, pendidik harus memiliki sikap menghargai, menerima, dan percaya terhadap peserta didik. Menghargai pendapat, perasaan, dan sebagainya menyebabkan timbulnya penerimaan akan sesuatu dengan lainnya; Ketiga, memiliki rasa empati. Untuk melahirkan situasi dan kondisi belajar atas dasar inisiatif diri, maka pendidik mesti memiliki rasa simpati dan empati terhadap setiap reaksi yang ditimbulkan peserta didik (Anwar, 2017, hal. 249).

Ciri-ciri pendidik yang berhasil berperan sebagai fasilitator dalam teori belajar Rogers adalah: 1) Pendidik dapat merespons perasaan peserta didik; 2) Pendidik dapat menghargai dan menggunakan ide-ide peserta didik untuk melaksanakan interaksi yang sudah dirancang; 3) Pendidik mengajak peserta didik untuk berdialog dan berdiskusi di kelas; 4) Pendidik bisa melihat kesesuaian antara pelaku dan perbuatan; 5) Pendidik bisa menyesuaikan isi kerangka berpikir peserta didik; 6) Pendidik sering melempar senyuman kepada peserta didik (Rogers, 1982, hal. 111).

Sebagai fasilitator, pendidik juga harus memiliki kesadaran yang sensitif bagi jalannya proses pembelajaran dengan tidak menilai atau mengevaluasi hasil belajar peserta didik. Karena pemahaman materi pembelajaran dilihat dari perspektif peserta didik, bukan dari perspektif pendidik. Oleh karena itu, pendidik harus dapat masuk atau merasakan apa yang peserta didik rasakan (Palmer, 2006, hal. 91).

\section{Taman Belajar Asmaul Husna Sebagai Lokasi Penelitian}

Taman Belajar Asmaul Husna didirikan pada tahun 2018 di bawah naungan Yayasan Asmaul Husna yang didirikan oleh Drs. H. Ibnu Hajar Baedlowei. Pendirian lembaga ini adalah dalam rangka mendukung pelaksanaan pendidikan pra-sekolah serta memberi kesempatan belajar kepada anak usia dini di daerah Petukangan Utara dan sekitarnya, karena ada rasa keprihatinan dari pendiri melihat anak-anak usia 4-6 tahun yang berkerumun, bermain-main di jalan dan di gang-gang tanpa aktivitas edukatif. Awal penentuan nama Taman Belajar Asmaul Husna itu dengan berbagai pemikiran, kenapa taman harus disebut dan tidak disingkat atau tidak dengan sebutan TK seperti pada umumnya, karena taman itu identik dengan segala sesuatu yang menyenangkan. Dengan demikian sangat diharapkan bahwa lembaga ini menjadi tempat yang sangat menyenangkan untuk belajar. Tim fasilitator atau para guru berkeyakinan bahwa dengan bermain peserta didik akan terlatih fisik motorik-nya, terbangun kerja sama, dalam bermain juga mereka akan mendapatkan tantangan dan masalah sesuai dengan kreativitas dan pengalaman bermainnya.

Berkat dukungan dan kerja sama dengan masyarakat di sekitar serta atas kesadaran orang tua bahwa usia pra-sekolah merupakan masa emas (golden age), masa yang sangat baik untuk memperoleh pendidikan pra-sekolah, lembaga ini dapat berjalan dengan maksimal. Tanggal 28 Agustus 2018 dimulai kegiatan belajar mengajar. Beberapa guru yang aktif adalah Arsikh Mawaddah Warrohmah (kepala sekolah), Ibu Siti Wahyuni (motor penggerak), dan Sri Mulyani guru (fasilitator). Pembiayaan 
di lembaga ini menggunakan sistem infak sukarela, dengan demikian secara tidak langsung, pihak sekolah selalu melibatkan orang tua peserta didik dalam setiap aktivitas pembelajarannya.

\section{Operasionalisasi Teori Pendidikan Humanistik}

Pendidikan anak usia dini merupakan salah satu bentuk pendidikan yang menitikberatkan pada peletakan dasar bagi tumbuh kembangnya fisik anak (koordinasi motorik halus dan menyeluruh), kecerdasan (kemampuan berpikir, kreativitas, kecerdasan emosional, kecerdasan spiritual), dan emosi sosial (sikap, perilaku, dan rasa beragama) bahasa dan komunikasi, sesuai dengan keunikan dan tahapan perkembangan yang dialami oleh anak-anak seusia ini (Ariyanti, 2016, hal. 50-58).

Penyelenggaraan Pendidikan Anak Usia Dini memiliki beberapa tujuan, yaitu: 1) Tujuan utamanya adalah membentuk anak Indonesia yang berkualitas yang dapat tumbuh dan berkembang sesuai dengan tingkat pertumbuhannya sendiri, sehingga siap sepenuhnya memasuki pendidikan dasar dan kehidupan setelahnya. kedewasaan. 2) Tujuan dari pendamping adalah membantu anak mempersiapkan diri untuk bersiap ke sekolah (Hajati, 2018, hal. 17-24).

Dewasa ini banyak lembaga pendidikan yang mempromosikan beraneka macam program unggulan dan program-program terbaik demi menjadi sekolah rujukan dan unggulan di daerahnya, tetapi di Taman Belajar Asmaul Husna, menciptakan desain pembelajaran yang humanis bertujuan untuk menciptakan lulusan yang cerdas baik intelektual, emosional, dan spiritual tanpa adanya paksaan dan ancaman sehingga para peserta didik nyaman dan bahagia ketika berada di lingkungan sekolah. Melalui pendekatan pendidikan humanistik, tim fasilitator atau guru berkeyakinan bahwa setiap peserta didik memiliki potensi yang dapat dikembangkan secara aktual, seperti memiliki kesadaran, kebebasan dan tanggung jawab sebagai makhluk individu dan sosial yang tidak hanya mementingkan dirinya sendiri tetapi berkeinginan untuk mengabdikan dirinya pada masyarakat. Demikian juga dengan kurikulum yang digunakan, tentu saja kurikulum ini mengacu pada kurikulum nasional, namun pada pendidikan anak usia dini, kurikulum dikembangkan dengan memasukkan berbagai inovasi pembelajaran yang dapat menyenangkan, membahagiakan pserta didik di semua mata pelajaran yang disajikan secara terintegrasi dalam tema kehidupan sehari-hari.

Rasionalitas pengembangan model pembelajarannya beranjak dari adanya perbedaan karakteristik peserta didik. Untuk memfasilitasi keragaman karakteristik siswanya, lembaga ini menggunakan teknik belajar Joy Full Learning, Integrated Learning dan Thematic Learning, sebagai usaha untuk memberikan kebebasan kepada siswa untuk mengeluarkan seluruh potensi yang dimilikinya (self-respect, self-reliance, self-confidence) (Adie, Kleij, \& Cumming, 2018, hal. 1-11).

\section{Joy full Learning dan PAIKEM}

Pembelajaran dengan teknik Joy Full Learning bertujuan untuk menciptakan suasana belajar yang aktif, inovatif, kreatif, efektif dan menyenangkan (PAIKEM) bagi peserta didik. Menciptakan suasana belajarnya menyenangkan bukan berarti selalu mengajak peserta didik untuk bermain-main, tetapi guru berusaha menciptakan suasana menyenangkan dalam setiap kegiatan pembelajaran. Dengan mengajak peserta didik dalam kegiatan belajar, mereka berperan aktif dalam mencari yang kemudian mengolah informasi yang diperoleh. Tentu saja proses pencarian ini berbeda-beda, karena setiap anak memiliki keunikan karakteristik, mulai kecerdasan dominan, tingkah laku, sehingga bentuk reward dan apresiasi juga berbeda-beda.

Menurut Wahyuni, pada prinsipnya teknik belajar ini bermaksud untuk menciptakan situasi belajar yang menyenangkan, nyaman, namun tetap aktif dan efektif bagi peserta didik. Untuk itu, dia menggunakan teknik pembelajaran yang dapat menarik perhatian sehingga peserta didik terlibat langsung dalam kegiatan belajar, misalnya dengan metode demonstrasi, mewarnai gambar kemudian dijelaskan maksudnya, bermain kartu abjad, kuis serta make a match, bercerita dan tentunya model bernyanyi dan bermain. Dengan demikian peserta didik tidak hanya berpikir dengan otak kiri tetapi juga memainkan otak kanan sehingga seimbang (Wawancara dengan Siti Wahyuni, 17 April 2020). 

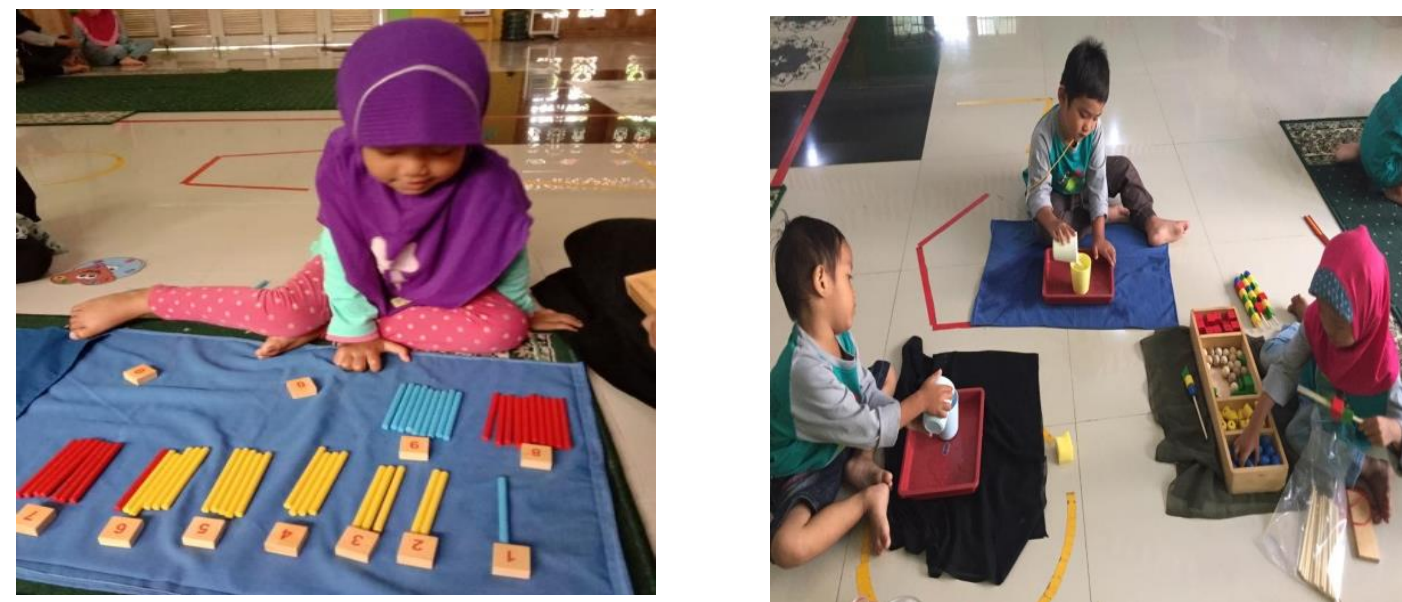

\section{Gambar 2. Mencocokkan angka dengan jumlah benda dan Belajar Menggunakan Media}

Setiap aktivitas belajar mengajarnya para guru atau tim fasilitator selalu berusaha menciptakan proses pembelajaran yang menyenangkan. Pihak pengelola lembaga pun selalu memberikan motivasi kepada para guru, agar selalu berinovasi dalam proses pembelajaran, sehingga peserta didik menjadi termotivasi dalam mengikuti setiap aktivitas di dalamnya. Selain itu guru membuat konsep pendidikan yang dapat menumbuhkan nilai-nilai agama, menumbuhkan cinta tanah air, dan juga peserta didik tidak merasa terbebani saat belajar sehingga potensi dan keterampilan dapat ter-asah yang nantinya bisa dipraktikkan dalam kehidupannya di masa depan (Wawancara dengan Arsikh Mawaddah Warrohmah, 17 April 2020).

Tidak hanya pada teknik pembelajaran saja, tetapi juga dalam situasi dan kondisi serta lingkungan belajar juga ikut mendukung teknik pembelajaran Joy Full Learning. Para guru mendesain ruang kelas se-kreatif mungkin agar saat berada di dalamnya peserta didik merasa nyaman sehingga potensi alamiah peserta didik dapat ter-explore dengan sendirinya (Wawancara dengan Sri Wahyuni, 17 April 2020).

Gagasan-gagasan pendidikan humanistik Rogers berpengaruh terhadap pikiran dan praktik pendidikan. Melalui teknik ini, proses pembelajaran di kelas menjadi lebih manusiawi karena sesuai dengan kebutuhan dan tingkatan peserta didik. Teknik ini juga memotivasi hasrat belajar menjadi lebih maksimal, seperti dalam permainan lego dan puzzle. Jenis permainan ini selain menyenangkan bagi anak dan dapat mengeksplorasi potensi peserta didik khususnya yang terkait dengan otak (intelektual) dan motorik (emosional). Awalnya anak hanya melempar-lempar lego dan puzzle tanpa memainkannya, Selanjutnya, anak termotivasi dan memiliki kemampuan untuk mencari dan mengakai serta menyusun lego dan puzzle dengan baik.

Selain itu, melalui teknik Joy Full Learning ini, anak dapat belajar atas inisiatif sendiri sebagaimana ciri dari teori pendidikan humanistik Rogers, bahwa akan sangat bermakna ketika belajar dilakukan atas inisiatifnya sendiri. Peserta didik dapat memilih arah belajarnya sendiri, sehingga mereka memiliki kesempatan untuk menimbang dan membuat keputusan dan membuat pilihan dan mampu introspeksi diri. Ketika peserta didik bergantung pada dirinya sendiri, maka kepercayaan dirinya akan semakin baik. Untuk menumbuhkan rasa inisiatif peserta didik, guru memulainya dengan memberi contoh, kemudian peserta didik biasa meniru karena sebagaimana tabiat anak-anak mereka lebih banyak meniru apa yang sudah dilihatnya daripada sesuatu yang dirinya dengar. 


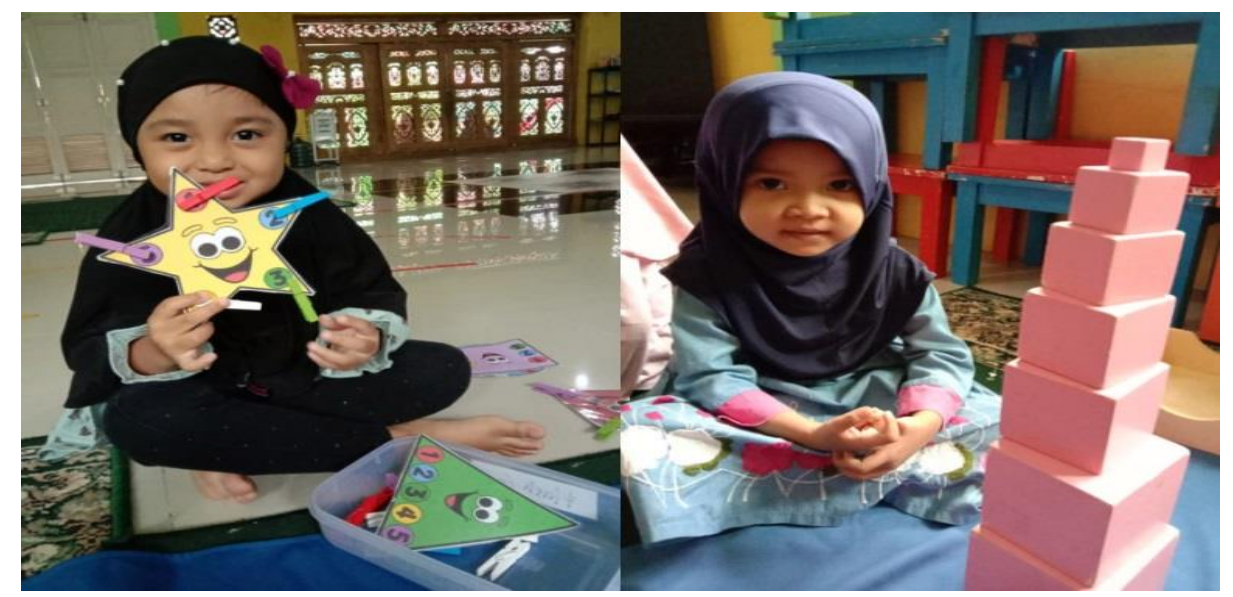

Gambar 3. Belajar Menggunakan Berbagai Media Pembelajaran

\section{Integrated Learning dan Partisipasi Orang Tua Siswa}

Implementasi dari teknik pembelajaran Integrated Learning di Taman Belajar Asmaul Husna, umumnya dilakukan melalui sosialisasi kepada orang tua peserta didik pada saat awal tahun pelajaran baru. Program yang disosialisasikan meliputi: metode pembelajaran, model pembelajaran, dan aktivitas terkait. Sosialisasi ini bertujuan agar orang tua dan peserta didik dapat melakukan persiapan dalam menghadapi kegiatan pembelajaran dengan optimal. Dalam konteks Integrated Learning, lembaga ini menjadi mitra orang tua dalam mendidik anak, karena orang tualah yang sesungguhnya memiliki peran dan fungsi pertama dalam mendidik anak-anak mereka. Di samping itu, diterapkan teknik belajar ini juga bertujuan untuk sebagai antisipasi terhadap anak yang tidak patuh, malas atau tidak memiliki motivasi dalam mengikuti pembelajaran (Wawancara dengan Neneng Soleha, 17 April 2020). Kurikulum dirancang semaksimal mungkin untuk menstimulasi dan agar segera bisa di-follow up orang tua di rumah. Guru juga melakukan brainstorming melalui video, apalagi pembuatan video pembelajaran di masa pandemi sekarang sangat penting untuk dilakukan. Aktivitas orang tua dalam konteks integrated learning terlihat pada gambar dibawah ini:

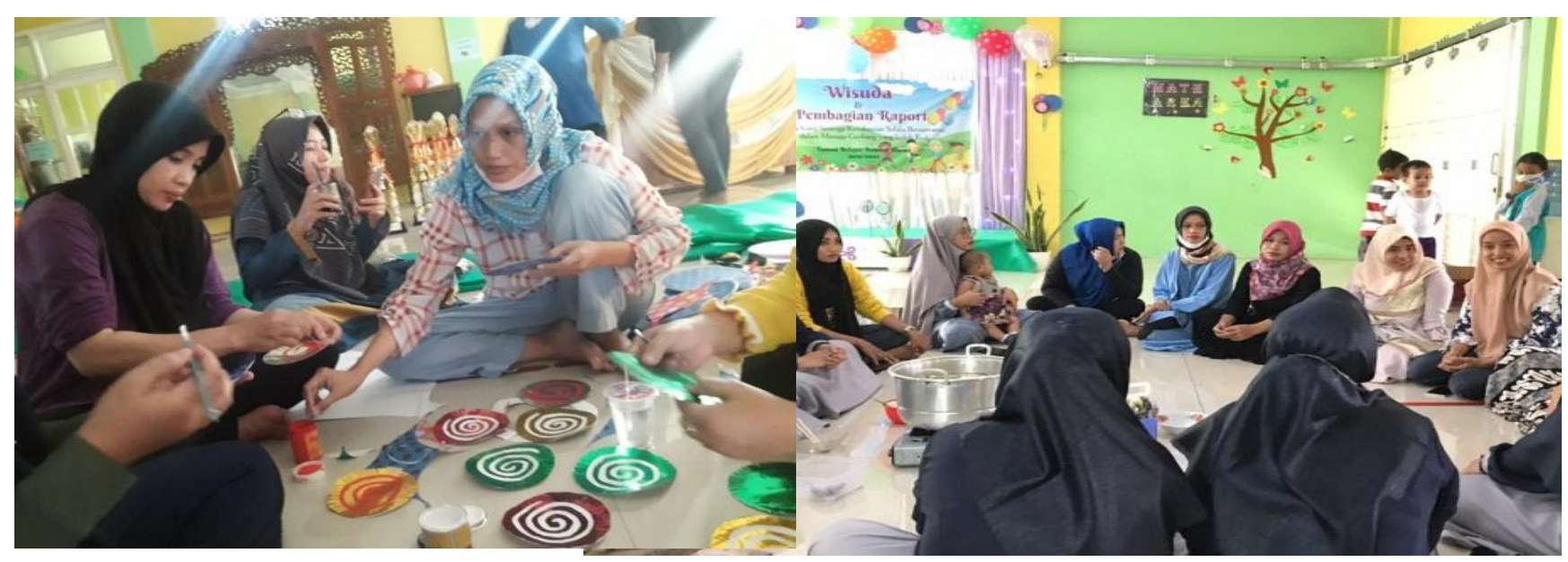

\section{Gambar 4. Para orang tua peserta didik terlibat dalam persiapan sebuah acara akhir tahun ajaran}

Ada banyak aktivitas belajar yang dilakukan melalui Integrated Learning, seperti pelibatan orang tua dalam peringatan hari-hari besar agama. Di sini orang tua dan guru berbagi peran dalam memberikan pembelajaran. Beberapa contoh aktivitas edukatif yang dilakukan orang tua adalah menyusun acara dan menghias tempat acara. Pelibatan orang tua dalam aktivitas belajar, juga 
dilakukan dalam kegiatan kunjungan ke beberapa tempat yang dinilai edukatif, seperti Moving Learning ke Pabrik Pepsodent, kolam renang, taman kota, dan berbagai tempat lain yang mendukung. Ini dilakukan untuk merangsang perkembangan intelektualitas anak dengan melihat secara langsung fenomena sosial dan fenomena alam yang bertujuan untuk memaksimalkan kebutuhan fisik-motorik, kerja sama, bounding antara sesama teman dan orang tua. Untuk memaksimalkan teknik Integrated Learning, guru dan para orang tua membuat program silaturrahmi yang diikuti oleh orang tua dan guru secara rutin setiap 2 bulan sekali. Rutinitas rapat ini bertujuan untuk menguatkan komitmen serta persamaan persepsi yang telah dirumuskan agar tercipta rasa saling memiliki antara guru, orang tua, dan pengelola lembaga.

Jika dihubungkan dengan konteks perubahan dalam belajar Rogers, prinsip ini menekankan bahwa belajar yang paling berarti adalah belajar tentang proses bagaimana belajar dan ini bisa dilakukan dengan melibatkan orang tua sebagai salah satu aktor pendidikan.

\section{Thematic Learning dan Integrasi Kecerdasan}

Teknik pembelajaran Thematic Learning di Taman Belajar Asmaul Husna dilakukan melalui pendekatan integrasi-interkoneksi dari beberapa materi pelajaran yang dibingkai dalam satu tema atau topik pembahasan. Hal ini bertujuan untuk meningkatkan tiga kecerdasan alamiah yang dimiliki anak, yaitu kecerdasan intelektual, kecerdasan emosional, dan kecerdasan spiritual. Beberapa contoh dari Thematic Learning seperti:

1. Anak-anak berbaris dengan rapi sesuai kedatangan sebelum masuk kelas, setiap anak mendapat giliran untuk memimpin barisan dan memimpin do'a. Lalu masuk kelas dengan mengantri.

2. Senam bersama yang bermanfat untuk mengembangkan kemampuan motorik, menumbuhkembangkan aspek fisik dan kemampuan serta kreativitas gerak anak, melatih keseimbangan ragawi, meningkatkan kekuatan dan kualitas mental anak, melatih ingatan, serta dapat mengurangi risiko terkena penyakit (jantung, stroke ) saat dewasa.

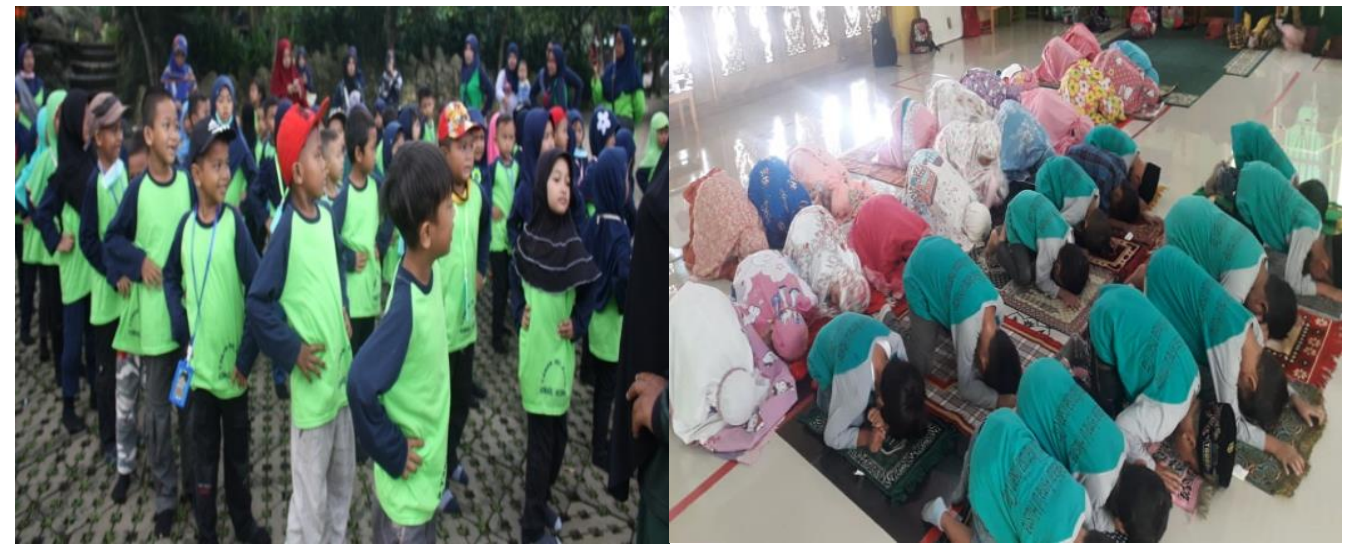

\section{Gambar 5. Senam Bersama Sebelum Melakukan Kegiatan Belajar dan Rutinitas Salat Duha}

3. Salat Duha berjamaah dilaksanakan pada pagi hari sebelum kegiatan belajar mengajar dimulai. Kegiatan ini bertujuan selain untuk meningkatkan dan menanamkan nilai-nilai keimanan dan ketakwaan peserta didik yang berujung pada kesucian lahir dan batin, yang tidak kalah pentingnya adalah kegiatan ini bertujuan untuk meningkatkan kedisiplinan utamanya dalam menghargai waktu. Anak laki-laki mendapat giliran menjadi Imam salat duha. Dengan kegiatan ini secara otomatis anak-anak menghafal do'a salat, belajar tertib, dan rapi dalam pengaturan barisan (shaff) salat. Tidak hanya sampai disini, setelah salat pun anak-anak diajak dzikir dan do'a bersama.

4. Pembiasaan kegiatan peduli lingkungan dilakukan peserta didik dengan senang dan gembira menjadikan lingkungan sekolah yang bersih dan nyaman. Lingkungan yang bersih menjadi 
cermin kehidupan yang sehat. Dengan adanya lingkungan yang bersih dan nyaman, peserta didik merasa betah di lingkungan sekolah.

5. Disiplin dan tertib dalam pemakaian alat edukasi dan permainan. Peserta didik diharuskan disiplin dan tertib dalam pemakaian alat edukasi dan permainan. Mereka saling bergantian dan tidak berebutan, setelah selesai menggunakan alat edukasi dan permainan, diwajibkan merapikan dan meletakkan kembali ke tempat semula.

6. Saling berbagi. Ini dilakukan pada saat snack time. Anak-anak dianjurkan untuk saling berbagi kepada teman-temannya.

7. Sebelum pulang, anak-anak kembali berbaris dengan rapi, fasilitator mengulas singkat materi hari itu, dan melempar beberapa pertanyaan ke peserta didik.

Dalam mengemas pembelajaran agar efektif dan efisien serta tidak membosankan, sekolah menggabungkan setiap kompetensi yang ada dalam tema pembelajaran dengan aktivitas sehari-hari. Dari sini teknik pembelajaran Thematic Learning diaplikasikan sebagai teknik pembelajaran yang baik untuk meningkatkan tiga kecerdasan peserta didik. Mulyani, misalnya mengutarakan, dalam tema tentang keluargaku, di sini dia mengajarkan berbagai macam adab kepada orang tua dan seluruh anggota keluarga. Tema ini masuk ke dalam mata pelajaran akidah akhlak (Wawancara dengan Sri Mulyani, 17 April 2020).

Teknik Thematic Learning juga dipraktikkan pada pembelajaran pengenalan alam yang bertujuan untuk mengenal berbagai jenis binatang, tetumbuhan dan segala yang ada di lingkungan sekitar. Untuk mewujudkan hal ini, strategi yang digunakan adalah melalui kegiatan eduwisata ke tempat bermain yang langsung bersentuhan dengan alam. Sehingga peserta didik dapat berimajinasi dari apa yang dilihat dan diamatinya.

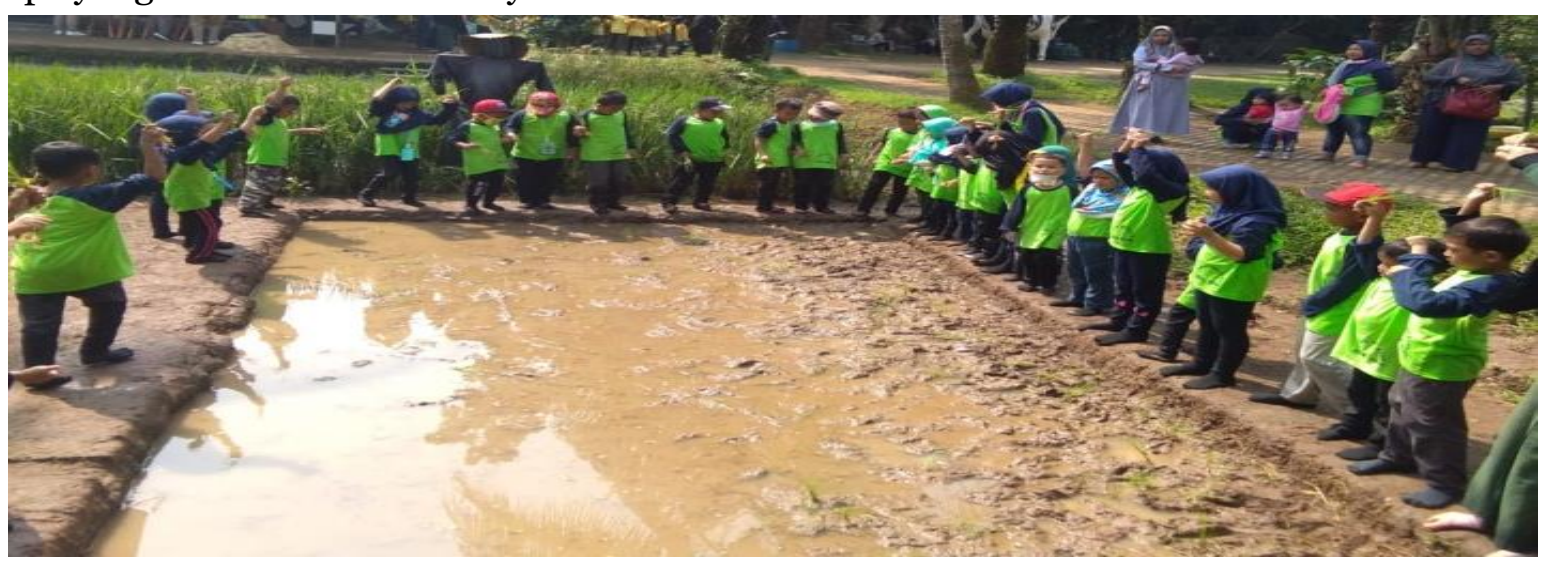

\section{Gambar 6. Belajar Mengenal Lingkungan}

Melalui teknik Thematic Learning ini, anak termotivasi menjadikan segala aktivitas pembelajarannya menjadi sebuah proses belajar yang berarti. Mereka bisa mengerti sesuatu jika materi itu ada relevansi dengan aktivitasnya sehari-hari, seperti mengenal tumbuhan, hewan, atau bahkan mereka cepat belajar menghitung uang "recehan" karena umumnya anak usia dini suka menggunakan uang receh untuk membeli sesuatu yang diinginkannya. Selain itu, melalui teknik ini anak bisa bebas belajar tanpa adanya ancaman. Proses pembelajran yang tanpa ancaman sebenarnya mudah dilakukan apabila dalam proses belajar-mengajar peserta didik dapat menguji kemampuannya, dapat mencoba pengalaman-pengalaman baru, bahkan ketika membuat kesalahan-kesalahan tidak ditemukan adanya kecaman yang menyinggung perasaannya. Jika kenyamanan sudah didapatkan, maka pembelajaran pun menjadi kondusif. Di samping itu, anak tidak merasa tertekan dan pendidik dianggapnya sebagai fasilitator yang menyenangkan. Misalnya: dalam belajar menggunting gambar, menempel, yang butuh kecermatan tinggi dan umumnya terdapat kesalahan, peserta didik tidak merasa takut jika melakukan kesalahn.

Demikianlah beberapa teknik pembelajaran di Taman Belajar Asmaul Husna sebagai cerminan operasionalisasi dari teori pendidikan humanistik, berupa Joy Full Learning, Integrated Learning, dan 
Thematic Learning. Semua teknik belajar tersebut merupakan langkah yang tepat untuk menggali potensi anak sekaligus untuk meningkatkan intelektual, emosional, dan spritualnya. Selain itu, dalam praktiknya, semua teknik belajar tersebut didukung oleh kemampuan para guru, orang tua, dan pengelola lembaga untuk bersama-sama berpartisipasi dalam mewujudkan program pendidikan di lembaga ini. Terbukti dengan meski tidak diwajibkannya pembayaran sekolah, tetapi orang tua dengan kedalaman sisi humanisme-nya memberikan infak kepada lembaga dengan ikhlas bahkan dan dalam situasi tertentu neraca keuangan di lembaga ini sangat sehat sehingga mampu melakukan berbagai macam inovasi pembelajaran.

Secara alamiah, setiap manusia yang dilahirkan memiliki potensi yang berbeda-beda. Potensi inilah yang menyebabkan manusia sering disebut educated people (manusia terdidik) yang kecerdasannya mulai tumbuh 50\% ketika memasuki usia 2-4 tahun (Tanu, 2017, hal. 17-27). Oleh sebab itu, potensi ini harus selalu mengerti dan dikembangkan oleh orang tua dan pendidik agar diberikan treatment dan bimbingan agar potensi yang dimiliki anak dapat berkembang sepenuhnya, meliputi berbagai aspek yang harus diberi perhatian secara seimbang. Karena jika pengembangan berbagai komponen pertumbuhan anak itu gagal, maka akan berdampak pada kegagalan dalam menyiapkan generasi yang tangguh, memiliki kejiwaan dan kepribadian yang utuh, yaitu kokoh dan matang dalam mengambil keputusan. Keberhasilan memberi perhatian pada semua aspek perkembangan ini akan berdampak pada kesuksesan anak dikemudian hari, baik secara akademik maupun sosial (Hasbiyallah, 2011, hal. 2).

Dalam perspektif teori pendidikan humanistik sebagaimana dinyatakan oleh Rogers di bagian awal, bahwa sebuah pendidikan sebenarnya adalah proses membimbing anak ke arah kebebasan dan kemerdekaan, mengenal dan mengetahui, serta dapat membedakan mana yang baik dan yang buruk, serta dapat memutuskan suatu tindakan dengan penuh tanggung jawab sebagai hasil dari belajarnya. Sebuah model pembelajaran yang mengedepankan aspek humanisasi sehingga seluruh potensi dan kecerdasan anak didik dapat dikembangkan. Karenanya tiga kecerdasan manusia, yaitu intelektual, emosional, dan spiritual pada dasarnya sangat ditentukan oleh salah satunya teori pendidikan yang diterapkan. Keterlibatan guru, orang tua, dan pengelola lembaga pendidikan juga menjadi salah satu unsur penting dalam mengimplementasikan proses belajar mengajar yang humanis.

\section{SIMPULAN}

Kajian ini menunjukkan bahwa perspektif teori pendidikan humanistik berkontribusi besar dalam meningkatkan potensi peserta didik meliputi kecerdasan intelektual, emosional, dan spiritual anak usia dini. Kegiatan ini diterapkan melalui teknik belajar joy full learning, integrated learning, dan thematic learning. Menciptakan suasana pembelajaran yang menyenangkan bukan berarti mengajak peserta didik untuk selalu bermain-main, akan tetapi para guru menciptakan yang dapat membuat peserta didik merasa nyaman dan bahagia dalam setiap kegiatan pembelajaran. Guru, orang tua, dan pengelola lembaga pendidikan sama-sama menyadari pentingnya keterlibatan mereka dalam aktivitas belajarmengajar tersebut. Kajian ini juga menunjukkan pentingnya kreativitas seorang guru dalam berkomunikasi, memilih pola asuh, dan berbagai stimulasi lainnya ketika melaksanakan proses pembelajaran baik di dalam kelas maupun di luar kelas. Tanpa adanya kreativitas guru dalam aktivitas pembelajaran, pengembangan dan peningkatan aspek kognitif, afektif, dan psikomotor, menjadi tidak maksimal, sebagaimana yang terjadi di beberapa lembaga pendidikan anak usia dini di Indonesia. Karenanya operasionalisasi teori pendidikan humanistik di lembaga pendidikan menjadi salah satu kunci penting dalam upaya mengembangkan potensi anak usia dini. Sebuah perspektif pendidikan yang mengedepankan aspek humanisasi sebagai sarana untuk mentransfer pengetahuan, mentransfer nilai-nilai kemanusiaan, dan mentransfer kebahagiaan.

\section{DAFTAR PUSTAKA}

Adie, L., Kleij, F. van der, \& Cumming, J. (2018). The development and application of coding frameworks to explore dialogic feedback interactions and self-regulated learning. British Educational Reasearch Journal, 44(4), 1-11. https://doi.org/https://doi.org/10.1002/berj.3463 
Anwar, C. (2017). Teori-Teori Pendidikan Klasik hingga Kontemporer (1 ed.; Y. Arifin, ed.). Yogyakarta: IRCiSoD.

Ariyanti, T. (2016). Pentingnya Pendidikan Anak Usia Dini Bagi Tumbuh Kembang Anak. JURNAL DINAMIKA PENDIDIKAN DASAR, 8(1), 50-58. https://doi.org/10.30595/dinamika.v8i1.943

Bahri, S. (2018). Ham dan Aktualisasinya dalam Pendidikan Islam. Jurnal AL-QALAM, 35(2), 173210. https://doi.org/http://dx.doi.org/10.32678/alqalam.v35i2.388

Dincer, D. (2019). Carl R. Rogers and Freedom to Learn: Teachers as the Architects of an Effective Learning Environment, and Techer's Attitudes. TPKP: luslararası Türkçe Edebiyat Kültür Eğitim Dergis, 8(4), 2341-2358.

Fahruddin, B. N. A. (2018). Pelatihan Program Parenting untuk Meningkatkan Profesionalisme Guru PAUD Di Kota Mataram Tahun 2018. JPMPI: Jurnal Pengabdian Magister Pedidikan IPA, 1(1), 37-44. https://doi.org/https://doi.org/10.29303/jpmpi.v1i1.206

Hajati, K. (2018). Pelaksanaan Pendidikan Holistik-Integratif dalam Pelayanan Kebutuhan Dasar Anak Usia Dini di Kabupaten Mamuju Sulawesi-Barat. Indonesian Journal of Educational Science (IJES), 1(1), 17-24. https://doi.org/https://doi.org/10.31605/ijes.v1i1.133

Hasbiyallah, M. S. (2011). Hadis Tarbawi. Bandung: Remaja Rosdakarya.

Herpratiwi. (2016). Teori Belajar dan Pembelajaran. Yogyakarta: Media Akademi.

Huliyah, M. (2016). Hakikat Pendidikan Anak Usia Dini. aș-șibyan, 1(1), 60-71. https://doi.org/http://dx.doi.org/10.32678/as-sibyan.v1io1

Hurlock, E. B. (2013). Perkembangan Anak Jilid 1 (Edisi Keenam). Jakarta: Erlangga.

J. Feist, G. J. F. (1998). Theories of Personality (4 ed.). Boston: McGraw-Hill.

Kusumawati, D. (2016). Sipervisi Akademik Kepala Sekolah Terhadap Manajemen Pembelajaran di PAUD. Satya Widya, 32(1), 1-8. https://doi.org/https://doi.org/10.24246/j.sw.2016.v32.i1.p4148

Lestari, N. G. A. M. Y. (2019). Program Parenting untuk Menumbuhkan Kesadaran Pentingnya Keterlibatan Orang Tua di PAUD. Pratama Widya: Jurnal Pendidikan Anak Usia Dini, 4(1), 817. https://doi.org/http://dx.doi.org/10.25078/pw.v4i1.1064

Lucas, F. M. M. (2017). The game as an early childhood learning resource for intercultural education. Procedia: Social and Behavioral Sciences, 237(1), 908-913. https://doi.org/doi: 10.1016/j.sbspro.2017.02.127

Mariana. (2019). Inspirasi Kisah Dalam Menstimulasi Character Building Anak Usia Dini. SCAFFOLDING: Jurnal Pendidikan Islam dan Multikulturalisme, 1(1), 58-66. https://doi.org/https://doi.org/10.37680/scaffolding.v1io1.43

Masdudi. (2016). KARAKTERISTIK PERKEMBANGAN PENDIDIKAN ANAK USIA DINI. AWLADY: Jurnal Pendidikan ANak, 2(1), 1-26. https://doi.org/http://dx.doi.org/10.24235/awlady.v2i1

Moleong, L. J. (2016). Metodologi Penelitian Kualitatif. Bandung: Remaja Rosdakarya.

Mulyasa, E. (2012). Manajemen PAUD. Bandung: Remaja Rosdakarya.

Nasution, R. A. (2017). Penanamana Disiplin dan Kemandirian Anak Usia Dini dalam Metode Maria Montessori. Jurnal Raudhah, $\quad$ 5(2), $1-16$. https://doi.org/http://dx.doi.org/10.30829/raudhah.v5i2.179

Natalie Shefer, et. all. (2018). Bringing Carl Rogers Back In: Exploring the Power of Positive Regard at Work. British Journal of Management, 29(1), 63-81. https://doi.org/https://doi.org/10.1111/1467-8551.12247

Nilma Zola, et. all. (2017). Karakteristik Anak Bungsu. Jurnal Konseling dan Pendidikan, 5(3), 109114. https://doi.org/https://doi.org/10.29210/120100

Nurdin, L. O. A. (2020). Evaluasi Pelaksanaan Standar Proses di Satuan Pendidikan Anak Usia Dini. Obsesi: Jurnal Pendidikan Anak Usia Dini, 4(2), 982-993. https://doi.org/https://doi.org/10.31004/obsesi.v4i2.485 
Nurjanah, S. (2018). Manajemen Pembelajaran Berbasis Standar Proses Pendidikan Anak Usia Dini.

Jurnal Penelitian dan Pengabdian Kepada Masyarakat UNSIQ, 5(3), 247-258. https://doi.org/https://doi.org/10.32699/ppkm.v5i3.472

Palmer, J. A. (2006). Fifty Modern Thingkers on Education (F. Assifa, ed.). Yogyakarta: IRCiSoD.

Qurrota A'yun, D. (2016). Peran Orang Tua Dalam Pendidikan Anak Usia Dini (Studi Kasus Pada Keluarga Muslim Pelaksana Homeschooling). Indigeneous, 13(2), 33-40. https://doi.org/https://doi.org/10.23917/indigenous.v13i2.2601

Rahelly, Y. (2018). Implementasi Kurikulum 2013 Pendidikan Anak Usia Dini (PAUD) di Sumatra Selatan. JPUD, 12(2), 381-390. https://doi.org/https://doi.org/10.21009/JPUD.122.21

Rogers, C. R. (1982). Freedom to Learn for the 8o's. California: Charles E. Meril Publishing Company.

Saihu. (2019). Konsep Manusia Dan Implementasinya Dalam Perumusan Tujuan Pendidikan Islam Menurut Murtadha Muthahhari. Andragogi, 1(2), 197-217. https://doi.org/https://doi.org/10.36671/andragogi.v1i2.54

Syamsu Yusuf, J. (2007). Teori Kepribadian. Bandung: Remaja Rosdakarya.

Tanu, I. K. (2017). Pentingnya Pendidikan Anak Usia Dini Agar Dapat Tumbuh dan Berkembang Sebagai Generasi Bangsa Harapan di Masa Depan. Adiwidya: Jurnal Pendidikan Dasar, 2(2), 129. https://doi.org/http://dx.doi.org/10.25078/aw.v2i2.96o

Usman, A. H. (2017). Humanism in Islamic Education: Idonesia References. International Journal of Asia-Pacific Studies, 13(1), 95-113. https://doi.org/http://dx.doi.org/10.21315/ijaps2017.13.1.5

Wigati I, M. M. (2017). Paradigma Humanisme Pendidikan Islam pada Anak Usia Dini. Raudhatul Athfal: Jurnal Pendidikan Islam Anak Usia Dini, 1(1), 1-17. https://doi.org/https://doi.org/10.19109/ra.vii1.1477 